
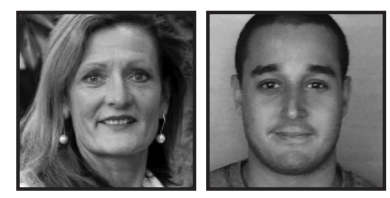

\title{
Transforming Environmental Awareness of Students Through the Arts and Place-Based Pedagogies
}

\author{
Tonia Gray and Cameron Thomson, Western Sydney University
}

\begin{abstract}
Incorporating the Arts into immersive place-based education programs can increase connectivity with the environment and facilitate the development of socially responsible and pro-environmental learners. Increasingly, children and adolescents are alienated and detached from the natural world. Given this noticeable shift, educators working in the outdoor setting need to rethink their modus operandi. Past attempts to promote learner connection with the environment have centred upon short-term stays and risk-centric approaches that embrace high adrenaline activities. This is the antithesis of Touched By The Earth, a yearlong place-based enrichment program using multi-modal creative methods with young learners to delve into the impact of experiential learning and how the Arts promote a personal relationship with the environment.
\end{abstract}

\section{The Context: Touched by the Earth as an Experiential Learning Program}

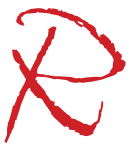

ecent educational shifts towards a more conscious connection with nature through ecological ways of experiencing, thinking, and knowing, are called "ecopedagogies" (Gray \& Birrell, 2015). "Touched By The Earth" (TBTE) is an Australian immersive place-based education enrichment program for Year 7 and 8 gifted and talented students, conducted over a school year. The TBTE Arts-based program was informed by the rich environmental, historical, and cultural heritage at Bundanon Trust and involved cross-curriculum studies in geography, history, and science. The nature of the research collaboration between Western 
Sydney University's researchers and Bundanon Trust is to ascertain if learners connect to nature in new ways through the practice of art-making in a place-based approach.

The program offered students the chance to be involved with artists and scientists connected with Bundanon Trust's SITEWORKS and their artist-in-residence program. Dialogue of students with artists, scientists, historians, and Aboriginal elders on the site sought to broaden the students' creativity and provide immersion in the place as a creative stimulus for film, dance, poetry, writing, drawing, and music. The program also links with Living Landscapes and Landcare Australia, which involved students in the removal of invasive exotic plants such as fireweed and lantana in an ongoing land restoration project at Bundanon Trust (see Figure 1). The specific activities in the immersive program included overnight camp at Bundanon, kayaking on the Shoalhaven River, exploring, drawing, and photographing that culminated in an artist book, and the creation of group projects to reflect learning for public exhibition.

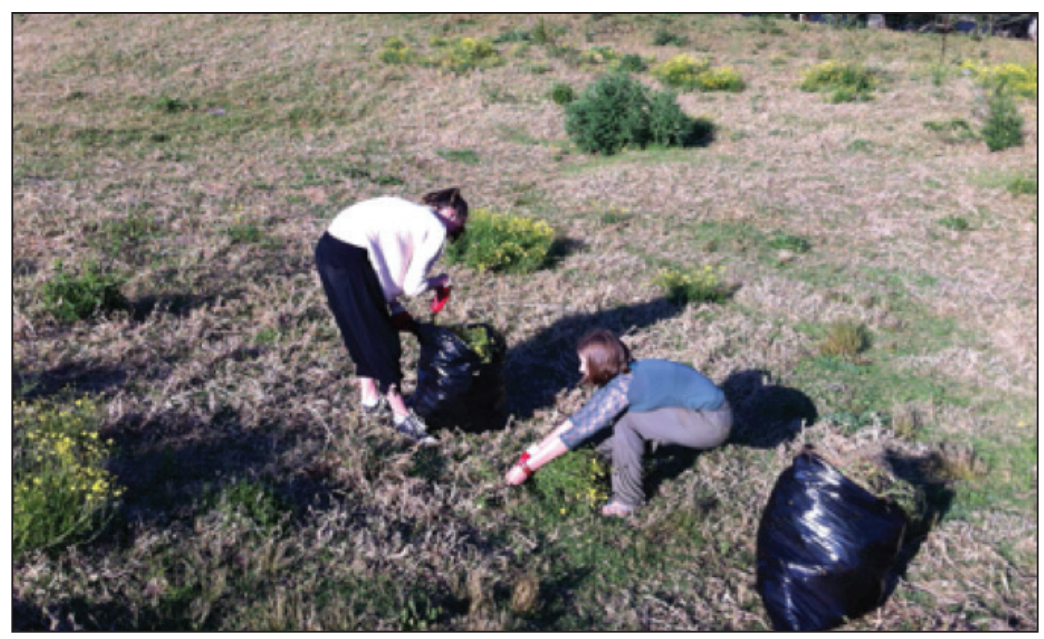

Fig. 1: Students as eco-warriors extracting noxious weeds

\section{Providing Transformative Experiences During Precarious Times}

Increasingly, pedagogues, and scientists recognize humanity's future rests on the degree to which we can live harmoniously with the natural world (Gray \& Birrell, 2015; Selhub \& Logan, 2012). Baba Dioum, a Senegalese naturalist and poet, encapsulates the need to focus on love and attachment in environmental advocacy when he states: 
In the end, we will conserve only what we love.

We will love only what we understand.

We will understand only what we are taught.

- Baba Dioum (1968, cited in Norse, 1993, p. 193)

Despite our ever-declining exposure to the outdoors and dire projections for the ecological future of the planet, educators realize that nature-based experiences can assist students in developing lifelong skills and a sense of "well-being." To this end, Quay (2015) believes that outdoor education is an imperative for post-school work and life capacities of learners. A strong push has begun to produce programs that balance the rational or scientific with the intuitive creative dimensions of education (Gruenewald, 2003a, 2003b). Educators in the field are now being challenged to rethink the epistemological foundations of education that not only eschew learners from the natural setting, but also fail to capitalize on the value that ecopedagogies offers teachers and learners. We believe that education requires not just increased awareness of our ecological reality, but also greater curiosity about and attachment to-perhaps even love for - the natural world (Birrell, Gray, \& Preece, 2013; Gray \& Birrell, 2013, 2015). How a student feels connected to nature is not considered in indoor settings, often through an emphasis of knowing over being (Quay, 2015). The affective and transformative relationship that students experienced and documented in the TBTE project exemplified the power of nature as a pedagogical tool, with one participant claiming:

It was so peaceful with the water lapping up against the banks.

When I was sitting on the beach like, I could feel the poetry pouring out of me and ... um

... my artwork ... I think I have drawn the best I have ever drawn in my whole life.

Our research questions include: What does it mean to be "Touched by the Earth," and how can the Arts amplify a personal relationship with the environment? This paper will explore how a felt connection with the natural world may be amplified through the Arts and a place-based approach. We also consider how the concept of "love" may be an integral component, both in the short-term relationships of humans with their environment, as well as the longer term sustainability and ethical responsibility of the human species towards its home: planet Earth. 


\section{Methodology}

A mixed methods research design incorporated both qualitative and quantitative data gathering. During the TBTE yearlong place-based program, the two researchers co-journeyed through the entire program with the participants and Bundanon educators. The qualitative data was collected from 19 students (10 males and 9 females) over six times (T1-T6) throughout the academic year. From T1-T6, data was obtained through interviews, quantitative instruments, photo-elicitation, student generated material such as artifacts, video, photos, and field observation. The schedule of activities and data collection points are indicated in Figure 2.

\begin{tabular}{|c|c|c|c|}
\hline $\begin{array}{l}\text { TEST } \\
\text { POINT }\end{array}$ & MONTH & DATA COLLECTED & TYPE OF DATA \\
\hline \multirow[t]{3}{*}{ T1 } & \multirow{3}{*}{$\begin{array}{l}\text { February } \\
\text { Pre-test (NR scale) } \\
\text { collection at school }\end{array}$} & Classroom activity & \\
\hline & & $\begin{array}{l}\text { Nature Relatedness } \\
\text { Scale }\end{array}$ & Quantitative \\
\hline & & Photo-elicitation & Qualitative \\
\hline T2 & $\begin{array}{l}\text { March } \\
\text { Site visit } 1\end{array}$ & One day & Observation \\
\hline T3 & $\begin{array}{l}\text { May } \\
\text { Site visit } 2\end{array}$ & One day & Observation \\
\hline T4 & $\begin{array}{l}\text { September } \\
\text { Site visit } 3\end{array}$ & $\begin{array}{l}2 \text { days and overnight } \\
\text { camp }\end{array}$ & Observation \\
\hline \multirow[t]{3}{*}{ T5 } & \multirow{3}{*}{$\begin{array}{l}\text { November } \\
\text { Site visit } 4 \\
\text { Post-test } \\
\text { (NRS scale) } \\
\text { collection at school }\end{array}$} & $\begin{array}{l}3 \text { days and } \\
2 \text { night camp }\end{array}$ & \\
\hline & & $\begin{array}{l}\text { Nature Relatedness } \\
\text { Scale }\end{array}$ & Quantitative \\
\hline & & Artifacts, Major works & $\begin{array}{l}\text { Qualitative Data } \\
\text { interview, film }\end{array}$ \\
\hline T6 & $\begin{array}{l}\text { December } \\
\text { Classroom visit }\end{array}$ & $\begin{array}{l}\text { One classroom } \\
\text { Debrief and reflections }\end{array}$ & Qualitative \\
\hline
\end{tabular}

Fig. 2: Program schedule and data collection points 
Journeying through the property at different seasons of the year, the students learnt about bio-diverse ecosystems at various locations on the property. The interdisciplinary nature of the program allowed students to engage with the Shoalhaven River through a kayak expedition and overnight camp at Bundanon. Additionally, poetry and drawing activities culminated in students' production of an artist's book.

Because of the desire on the part of researchers to gauge whether there was any shift in students' relationships with the natural world, participants were surveyed at the beginning and end of the academic year as a pre- and post-test using the Nature Relatedness Scale (NRS) (Nisbet, Zelenski, \& Murphy, 2009). Preliminary data suggests greater connection as a result of participation in the program. Although useful, survey data did not explore significant concrete questions about how students felt about nature. Affective relationships emerged more through the richness of interviews at the end of the program where students expressed attachments and feelings for places. After the research project, the researchers also wondered to what degree emotional links to specific sites like Bundanon-or for the Earth itself in a broader sense- might manifest in students' artistic, creative responses before they articulated a connection or responded in a measurably different way to the survey instrument. In other words, were artistic endeavours driving a changed relationship, and if so, would that changed relationship be evidenced in their artwork before it showed in surveys or interviews?

\section{Love, Attachment, and the Arts in Place-Based Pedagogies}

You must love the crust of the Earth on which you dwell more than the sweet crust of any bread or cake; you must be able to extract nutriment out of a sand heap.

(Thoreau, 1858)

Thoreau's statement firmly places "love" at the heart of our relationship with planet Earth. If Thoreau is correct that we "must love" the Earth—can we design an outdoor curriculum that encourages a transformation of the affective relationship students have with nature? Statements from a student such as: "the earth touched my heart and filled my soul ... I yearn for the land once more" (13 year-old female TBTE participant) reiterate the strong bond between nature and learner as well as how nature can serve as a learning vehicle. 
Renowned author Aldous Huxley (1946) posits: "We can only love what we know, and we can never know completely what we do not love. Love is a mode of knowledge" (p. 95). This maxim resonates deeply for a multitude of our daily behaviours, values, attitudes, and beliefs and, hence, the ways we act in the world. A strong affection, even a loving devotion, can provide powerful motivation to learn about, protect, and preserve the object of love. If the same holds true for pro-environmental attitudes, the affective transformation would necessarily be part of outdoor education. A pedagogy that can engender love of places or the environment in learners might transfer to a desire to protect those places.

An ever-growing body of significant research adds support to the argument that teaching outdoors in the natural environment promotes an appreciation and lifelong connectedness to nature (Chawla, 2007; Herbert, 2008; Hinds \& Sparks, 2008; Louv, 2008; Sobel, 1996). The notion of "appreciation" suggests a more ambiguously affective relationship: one can intellectually "appreciate" something, but fall well short of the emotional intensity suggested by "love." However, the historical criticism of anthropomorphism may discourage theorists from describing relationships with the environment in such strong terms.

Historically, adventure and outdoor educators have attempted to promote a human-nature connection primarily through risk-centric approaches incorporating adventure-fuelled and high-adrenaline activities. This high-risk, high-action approach has now been widely acknowledged as blinkered and myopic (Brymer, Downey, \& Gray, 2009; Brymer \& Gray, 2010; Mullins, 2011; 2014; Nicholls \& Gray, 2009). This paper is part of a broader movement in outdoor and adventure education to examine how "slowing down" the educative process and listening to the land can be a valid approach to magnify human-nature relationships (Martin, 2005; Nicholls \& Gray, 2008a, 2008b, 2009; Nicholls, Gray, \& Hoban, 2008; Payne \& Wattchow, 2008). It is imperative that discussions are premised on our acknowledgement of contradictory positions in the field of outdoor and adventure education where sometimes humans are pitted against nature.

Our current educative processes necessarily dissuade pro-environmental behaviours in learners as the environmental conundrums of the 21st century are presented as statistically dire and beyond human repair (Gray \& Birrell, 2015). 


\section{Nature Experiences as a Foundation for Environmental Advocacy}

A direct causal relationship exists between pro-environmental activities and a personal link to the natural environment, especially that made in the early developmental years (Carson, 1956; Dunlap \& Kellert, 2012; Gray, 2013; Kellert, 2012; Sobel, 1999). The affective and transformative qualities of outdoor education are somewhat sidelined to the dominant epistemic foundations of education that disregard how a sense of "being" and learner experiences in the classroom are crucial to the promise of education (Quay, 2015). Moreover, a child's disconnection and alienation from nature is a valid concern for 21 st century educators struggling to combat issues of unsustainable resource use and environmental degradation (Birrell et al., 2013; Gray \& Martin, 2012; Kahn \& Kellert, 2002; Louv, 2008; Orr, 2002, 2004). All indicators suggest that we as educators are working with children who have experienced a denaturalized childhood (Gray, 2012, 2013; Kellert, 2012; Lloyd \& Gray, 2014; Louv, 2008). The isolation begs the question of how we get children to love something they do not know first hand and, more importantly, how do we redress the imbalance. At the heart of this process is a personal dynamic Sobel (1996) observed: "What's important is that children have an opportunity to bond with the natural world, to learn to love it and feel comfortable in it, before being asked to heal its wounds" (p. 10).

Seminal work in the field of social psychology by Fishbein and Ajzen (1975) and Ajzen and Fishbein (1980) argued that knowledge alone is not a precursor to behaviour change. Along the same train of thought, educators in the outdoor and environmental field have consistently argued that knowledge and cognition alone are not enough to produce pro-environmental behaviours in children (Cheng \& Monroe, 2012; Cornell, 1998; Herbert, 2008; Martin, 2005). Our nature-estranged lifestyle may have a direct causal relationship to our lack of love and connection to the Earth and our treatment of the natural world as if it is a dispensable luxury. This disconnect from the natural world is somewhat derived from the performancecentred culture in schools that does not view nature-infused learning as the vehicle to help students achieve (Quay, 2015). Such self-realization of the value to be found within the environment was aesthetically put in one 14 year-old girl's poem in the TBTE program, likening her outdoor experience to that of utopia: 
Forgotten amongst

The looming giants;

Creating shadows,

Which consume

Her soul,

Binding her.

\title{
Whatever happened to Utopia?
}

To living at peace

With minds at ease

\author{
Instead we were \\ Confined to \\ Prisons of four walls \\ And calendars \\ And clocks \\ Tick-tock-tick-tock \\ Too fast \\ Too fast
}

Similarly, the disconnect with the four walls was iterated in a student reflection of the TBTE that paralleled this notion: "people have been saying how in school we are limited to four walls and there is nowhere near as much inspiration-the kind of charts by time limits and expectations-everything (at school) is going a hundred kilometres an hour." To slow down the educative process and listen to the land would be a requirement to avoid the constraints of indoor settings and feel "free," as one boy observed: "you don't have a time limit, so you are not rushing; so all your ideas just come to you, they are flowing." There is realization of the affective powers of nature and the current predicament whereby traditional instruction is seen as increasingly outdated. Although nature-infused learning experiences appear to offer substantial benefits for students, Selhub and Logan (2012) reported that in the hypermediated world of screens, our sense of stewardship towards the environment is diminished as we view the natural world as increasingly primitive.

Two of the most respected researchers in the field of environmental education, Kellert (2002) and Orr (2004), uphold the belief that simply having a cognitive understanding of environmental issues may have little influence upon behaviour. Herbert (2008) also finds that, "simply knowing about environmental issues has little impact upon behaviour" (p. 63). Collectively, the research suggests that education 
does not simply confront a knowledge problem, but also an affective challenge at the same time. The gap between environmental knowledge and pro-environmental behaviour has been well documented, for example by Ellsworth (2013), Gray and Birrell (2013), and Kollmuss and Agyeman (2002). Quite clearly, a purely intellectual understanding of environmental degradation is not enough to inspire action or behaviour change (Milton, 2002; Pooley \& O'Connor, 2000). Our current teaching and learning practices dissuade the acquisition of pro-environmental attitudes as it is presented as something statistically dire that cannot be fixed (Gray \& Birrell, 2015). Along these lines, Orr (1993) claims that a necessary precursor to environmental stewardship is deep love and affection for our planet. Without such a relationship, pro-environmental behaviour and the sustained impacts of outdoor and adventure education may not be realized.

\section{The Emotions and Learning}

Despite being neglected in the research, the affective domain has increasingly been shown to be crucial in all aspects of learning (Arnold, 2005; Csikszentmihalyi, 1990; Hinds \& Sparks, 2008; LeDoux, 1992, 1997, 2003; Stern, 1985). The manner in which the affective domain is incorporated into the classroom environment has a direct correlation with student engagement and indelible learning (Hinds \& Sparks, 2008; Kellert, 2002). Arnold (2005), in an Australian context, has designated a field of pedagogy called "empathic education" where emotional literacy is privileged in the same way that cognition has been to date in educational systems. Students can be taught to understand and express their own emotions and empathize with others, building love and trust in the classroom. A range of research shows that emotions such as surprise, anger, joy, distress, love, intrigue, fear, attachment, contempt, disgust, passion, interest, and shame need to be activated in order to initiate lifelong learning and behaviour change (Kudryavtsev, Stedman \& Krasny, 2011; Liefländer, Fröhlich, Bogner, \& Schultz, 2012; Perkins, 2010). Of course, to "activate" may be easier said than done. Surely, the development of empathy and forging ties with animals (or plants, for that matter) continues as a lifelong habit, rather than merely designated between the ages of four and seven. A strictly staged pedagogy would also seem to suggest that affective development occurs in a predictable and stepwise fashion, a suggestion that we think is questionable. 


\section{The Arts as a Catalyst for Transformation}

Since humans first put pigment on cave walls, nature has inspired artists of all types as both the wellspring and focus of our creativity. More recently, environmental activism has stimulated the Arts across the globe, for instance Björk in Iceland, Robert Bateman in Canada, Ansell Adams in the US, Andy Goldsworthy in the UK, and Arthur Boyd in Australia. Arthur Boyd, for example, painted a series of artworks that expressed his pain over the threat and damage to his beloved Shoalhaven River. This series of works was one way among many that he engaged in Arts-based environmental activism. When you ask people what they like to do in their spare time, "virtually everyone will identify an activity connected with the Arts, the body, or the natural world" (Upitis, 2011, p. 1). Based upon these other research results, TBTE sought to demonstrate that the Arts, embodied learning, and artistic engagement with the natural world could be integral components of outdoor programs, especially to promote affective ties to nature. Embodied learning, love, affinity, compassion, and well-being are recurrent themes in relation to environmental education within contemporary research (Gray \& Birrell, 2013). Because nature-infused learning experiences evoke powerful emotions, the Arts are a powerful tool for engaging students in cross-curriculum learning (Jacobson, McDuff, \& Monroe, 2007).

\section{Findings: The Design Elements of "Touched by the Earth" Program}

The delivery of outdoor and adventure education programs has tended to focus on the physicality of the outdoor experience as a way to engender environment appreciation (Nicholls et al., 2008). A subtler interdisciplinary approach, such as that advocated by Nicholls and Gray (2008a, 2008b, 2009), characterizes TBTE. It is worth teasing out some of the components of the TBTE program in order to shed light on the relationship between nature and learner.

\section{Immersion Program}

The yearlong program encapsulated elements of embodied ecopedagogical learning (Green, 2012). A multi-sensory, immersive program that literally "touched the Earth" is part of experiential learning in the outdoors: hands flowing in water from kayaks that had no specific time imperative, hence, leaving those hands to explore 
their surroundings at will; a water dragon plucked from the stream for several minutes of gentle stroking by wary fingers; forceful hands jerking lantana clinging obdurately to the soil; and feet treading warily on rough ground when a student's eyes were blindfolded and her arms held by another sighted student. Smells, sights, and sounds were ingested by each student and then expressed through a variety of artistic modalities (Jones, 2013). The in-depth experience of the way bodies are themselves touching the Earth is no one-way directional field, but more a reciprocity of self and world.

Any objective account of outcomes might miss the deep affection that developed between one student and wombats, a continuing source of fascination at Bundanon for many urban youths. In fact, the students developed a profound appreciation, gratitude, and even love for the founder of this property. The researchers were intrigued by the joy, energy, and sheer enthusiasm of a group of students who, in the soaring heat of the Australian summer, threw themselves wholeheartedly into digging out invasive fireweed and lantana. Although the official outcomes of the research project, such as the inspiring outdoors program enriched through the Arts and artists by Bundanon Trust Education programs, were remarkable, the researchers were even more impressed by the emotional reactions of students to their environment.

The TBTE boys' video-devised, made, and filmed by students (http://youtu.be/ hxGtMajUpLc) provided images of vital bodies moving in places: jumping, risking, diving, digging wombat holes, flying through the air. In most modern outdoor education discourses, traditional classroom instruction is seen as the antithesis of holistic and transformative education. Countless participant self-reported claims about the impact of outdoor education over the years have shown that learners perceive the outdoor setting to be "free" from the constraints of the indoor, as emphasized in one of many anonymous TBTE comments:

\section{Tweet, Chirp, Squawk!}

I look up and see a flock of birds flying over happily,

They are truly alive,

No rules to weigh down there flight,

Life lived the way they want it ...

Why can't that be me...? 


\section{Embedding an Arts-Based Approach}

In TBTE, students recorded and expressed their observations and understandings in a myriad of ways: writing poetry, drawing, painting, performing dance, music, and digital film-making in order to broaden their own creativity through a multi-modal Arts-based approach (See Figures 3 and 4).

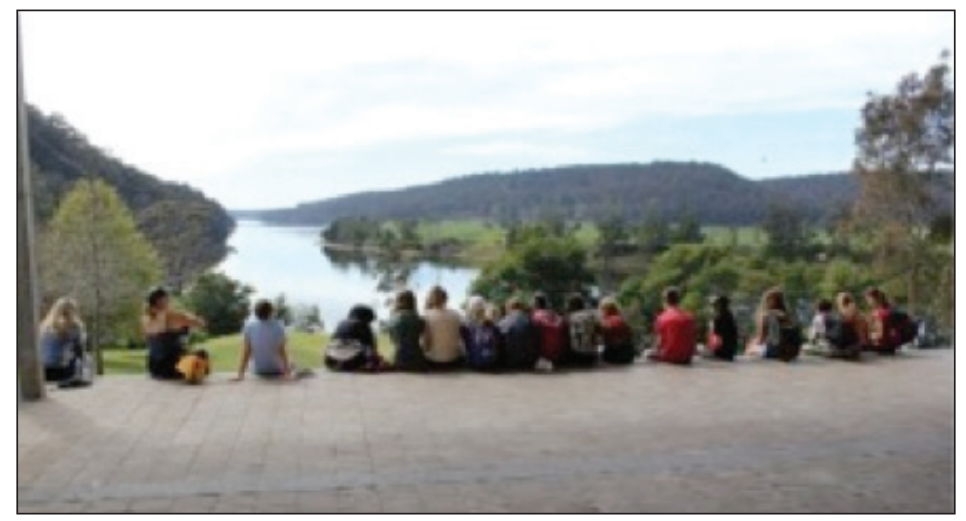

Fig. 3: Multi-sensory immersion activities

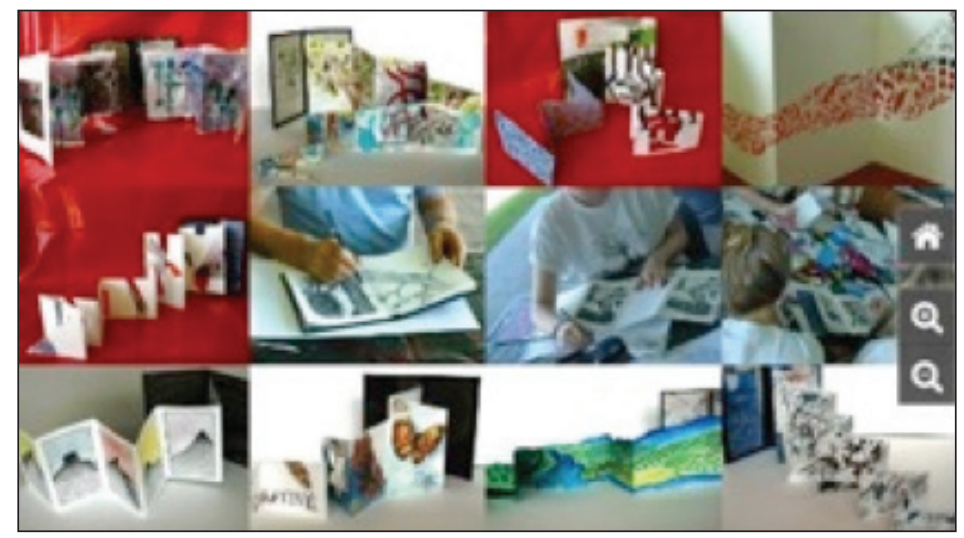

Fig. 4: Artefacts produced by students

The 2012 class was the Gifted and Talented class from a local high school. The program, devised and taught by the school, gave no specific emphasis to art or artistic responses. TBTE was viewed as an "enrichment" program by the school and by Bundanon Trust. Nonetheless, the way students had their creative selves activated may have been far more than what was envisaged in an enrichment program. 
Take for instance, one student's awakening to creative potential: "The connection between Earth and Art was triggered in me when I was painting. The brush strokes of the leaves and wind truly showed the beautiful aspect of the Earth."

Similarly, another student wrote: "We all have an artistic side and that is uncovered when we become closer to Earth."

A sense of "aliveness through active engagement in creative activities" (Frauenfelder, 2011 p. 194) motivated further student learning and deeper engagement in the site. A young female student seemed to contain a real sense of this "aliveness": "Art connected me to the Earth by making me notice things I wouldn't have noticed and also makes me appreciate the beauty of the Earth."

So the impact of art activities on connecting students to the natural world through TBTE seems to support research that asserts that the Arts leverage deep engagement and links with the natural environment (see Figure 5).

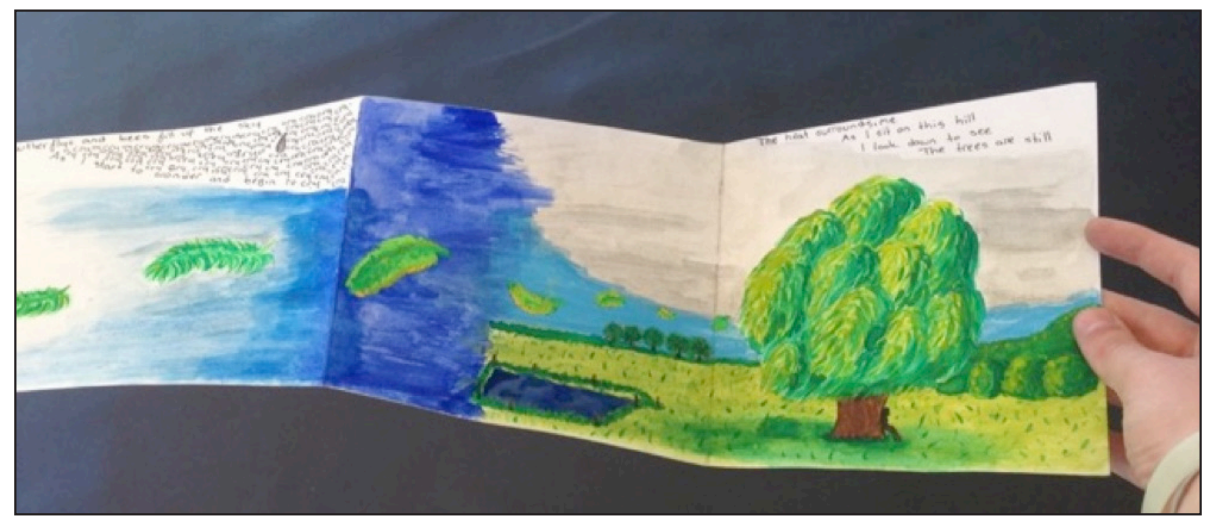

Fig. 5: "Dialogue" with the Shoalhaven River through drawing, poetry, and so forth in an artist book creation following kayaking on the river and poet-in-residence recital

Just as the students mentioned being "connected to the Earth" and becoming "closer to the Earth," another shared about the usefulness of creative work: "I think the art was important to express feelings and thoughts about the Earth."

However, these comments are quite general and do not reveal exactly what is being meant by being "close to the Earth," let alone how this affect actually arose throughout the yearlong program. The comments might be more indicative of researcher emphasis 
in designing interview questions, rather than a response by students. The very fact that the type of comments was included at all in the interviews, as stated earlier, took the researchers into an unanticipated way of understanding the data and making adjustments to the next iteration of TBTE. The students made us think about love and loving relationships because of what they had to say. Strong affects emerged as a thread throughout all the data as something of a surprise to the researchers.

\section{Nature-Infused Learning Through Place Pedagogy}

The importance of understanding, nurturing, and developing "place" relationships were the underlying imperative to this program. Somerville, Davis, Power, Gannon, and de Carteret (2011) state that we can understand and know ourselves differently by

...focusing not on one's individualized self, whose identity is constructed in its separation from others and from place, but on oneself in relation to those others, including human, non-human and Earth others, who make up the places we live in. (p. 1)

The Arts can be incorporated into the design of outdoor education settings and serve to not only emphasize the holistic qualities of teaching and learning potential that can be extracted through ecopedagogies, but also seek out the best of both epistemological and ontological worlds of education (Quay, 2015). Such an idea was reported by one 14-year old student who claimed that:

The earth and nature give us so much artistic energy.

So much that it is pouring through our veins and sometimes leaks out onto paper or through our mouths or takes control of our body... Bundanon, the earth, has been my safe haven.

Dancing by the river with only the gentle breezes and birds chirping as music that is to me like heaven ... I definitely feel as if I have been touched by the earth ...

The place-based learning model proposed by Sanger (1997) is a three-pronged model similar to the TBTE experience with the aim of building connections, building community, and using narrative. "Building connections" is an experiential, interdisciplinary approach to learning that develops students' skills, confidence, and understanding of the value of their place. "Building community" entails using cooperative learning strategies to involve all members of a place in the process of education. And "using narratives" means listening and learning from stories of the community members and the land and the ways in which they are intertwined. 
In the case of these TBTE Gifted and Talented students, the place (Bundanon) is local to their town (Nowra). The Shoalhaven River that so sharply defines the town and adjoins their high school (Bomaderry High) is the same river that flows through the Bundanon Trust properties. The river emerged through the data with a dominant role in the imaginary of many students. One remarked: "I felt connected to the river and even though I am not an artist I felt compelled to draw." Such statements reinforce the need for ecopedagogies to become a major consideration in traditional classrooms and curriculum. If nature-infused learning experiences can compel learners to undertake activities in the Arts, then surely such techniques are worth considerations in education.

With the benefit of researcher hindsight, it would have been productive to enquire initially into the pre-existing relationship of participants with their local river and more generally, their immediate environment. This preliminary inquiry may have revealed affective relationships with the river as well as other local knowledge. What emerged from interviews was the profound connection with the river, told through narratives, artworks, and performance.

TBTE involved more time being spent by students in the outdoors. The land itself is maintained as a working farm, although much of the property has become degraded due to weed infestation. This aspect of the place, besides the times spent in natural bush areas, seemed to trigger a strong response of caring and responsibility in students:

"During the year long program ... I felt like my connection with nature has thrived .... The whole experience has taught me how to work in conjunction with nature and how we co-exist."

"It has given me a better idea of how we should preserve our beautiful land. Without this land, I wouldn't have found my passion for nature. I love it!"

The study revealed that ecopedagogies which incorporate the Arts into their school curriculum, and recognize affective transformation, are a powerful vehicle for personal enrichment and build a bridge between classrooms and deep connections with the Earth. Such enrichment denoted the impact that outdoor and adventure education had on learners as well as their renewed perceptions of nature:

As I sit on the hill and look up to the sky,

I see the bright sunshine smiling by. I watch the ocean sparkling like a pearl, When the waves splash, slide, and swirl. 
As the birds start to chirp and tweet

The animals move and dance to the beat

Winds entertain me with their breathtaking story

Telling me of adventures and sometimes of glory

And, similarly:

This is nature this is earth

This is the mother who gave us birth.

We are different but we are one,

Living together under the sun.

\section{The Dialogic Dimension: Dialogue With the Natural World and Dialogue With Artists, Scientists, and Poets}

We felt that dialogue was integral to the experience of the TBTE program; however, because the impact is difficult to assess or measure, dialogical pedagogy is put forward here as a working hypothesis. Val Plumwood $(2000,2003)$ has categorically argued that dialogue is critical to place attachment, and Birrell (2007), Cameron (2003), and Cameron and San Roque (2003) have all used the notion of dialogue on Australian soil and through Indigenous contact. Birrell's research speaks of "an intimacy of place" acquired through a range of art modalities in response to places and Aboriginal cultural knowledge. Those art modalities dialogue with each other to create deeper layers of connectedness or intimacy:

What begins as a brief encounter, the first rudimentary beginnings of a relationship, then proceeds to develop into a deeper relationship, characterised by increased levels of intimacy...I do consciously continue to develop this relationship, to keep it alive and active and vibrant by continuing the dialogue begun in place. I feel I know that place and feel known by it. (Birrell, 2007, p. 288)

In most cases, relationships require time to develop into a deeper knowing of that other person-so too with places. Even further time is required to know some person or place intimately. Birrell (2007) speaks of dialogue as the means to establish intimacy. Had TBTE been a one-off program, intimacy with Bundanon would probably not have arisen. The students in this program enjoined various art modalities. Although the educators may not have been referred to dialogue explicitly, over time, the recurring encounters became "a dialogue begun in place." 
Of course, students were constantly interacting with each other throughout the yearlong program, both at school and on the Bundanon properties, either through words or through exchanging the artwork they produced. On another level, a design element was incorporated into the program through conversations and workshops with scientists, writers, artists, and poets who were on site as part of Bundanon Trust's programs for artists and performers in residence, with many outcomes seen in comments such as, "we all have an artistic side and that is uncovered when we become closer to the Earth." This design element extended the vision of potential creative outlets through which students could express a sense of place. The direct contact with professional artists and scientists, who addressed the students as serious scholars and artists, may have also contributed to the effectiveness of TBTE. For example, students were taken deeply into the research methods of wombat expert Dr. Phil Borchard; a poet read her river poems to the students on the banks of that same river, pointing out her inspiration and techniques before students wrote their own poems; two travelling artists from Melbourne who had cycled to Sydney showed the students what their diaries were like, the artworks they produced, and set up conversations around the nature of the artistic process. All of these dialogues opened up new worlds of imaginative possibility and suggested different ways to express oneself in relation to a place.

In a similar vein, students reported that the creation of group projects to reflect their learning at Bundanon Trust was experienced in immersive and entertaining ways: "so we made a video on just being in nature and having fun-a few stunts and things we made a montage, we edited all the videos together and put titles and music to it." Such an experience reiterates the need for educators to rethink their modus operandi and consider ecopedagogies as a sound tool for teaching and learning in the 21st century.

\section{Conclusion: Incorporating the Arts Into Ecopedagogies}

Incorporating the Arts with ecopedagogies was a fundamental educational choice for TBTE, which produced unexpected results, especially in the affective domain. The preliminary analysis of the TBTE data suggests that love and connection with the Earth are central to promoting deep engagement and indelible learning. Immersion programs such as this pilot project are instrumental in fostering a closer connectedness of students with the natural world through an Arts-based approach. 
An outdoor classroom that is student-centred encouraged stronger personal creativity and enhanced group cohesion and a sense of stewardship over the land, which is exactly the vision of the Boyd-Bundanon legacy. This view is conveyed in one student's voice and shows the impact of ecopedagogies on the perception of nature and the world for learners: "Art connects the Earth because Earth is a work of art. It is beautiful and inspiring. Everything on Earth itself is art."

Any of the student responses to the TBTE program emphasized that it was a valuable component in their development as pro-environmental and nature learners. This article examined different approaches to facilitating the relationship between art and nature as a model of place-based education underscored by an "ethically responsible pedagogy" which is dynamic, opportunistic, and relational (Sellar, 2009, p. 351 as cited in Somerville et al., 2011, p. 3). Further, we hope this paper has prompted outdoor and adventure educators to rethink long-held assumptions about the design of outdoor programs.

In the final analysis, students were unashamedly "Touched by The Earth" in ways rarely before witnessed by either researcher in previously implemented "traditional" risk-centric outdoor activities. Scottish Environmental Artist, Andy Goldsworthy, encapsulates our sense of hope in relation to a focus on connecting children to nature though Arts-based programs when he states:

We often forget that WE ARE NATURE.

Nature is not something separate from us.

So when we say that we have lost our connection to nature, we've lost our connection to ourselves.

$\sim$ Andy Goldsworthy

During the multi-sensory immersion program, students studied the world of the wombat, photographed a feather-tailed glider at night in the natural amphitheater and made damper, a traditional Australian soda bread, around the campfire. They had the opportunity to explore the artistic heritage of the site, draw, kayak the river, and pull noxious weeds from the property. The final residential visit enabled students to develop an individual creative project (see Figures 3 and 4) as a public art exhibition or performance based on their year's experience and responses to their engagement with nature, the artists, and the setting. 


\section{References}

Ajzen, I., \& Fishbein, M. (1980). Understanding attitudes and predicting social behavior. Englewood Cliffs, NJ: Prentice Hall.

Arnold, R. (2005), Empathic intelligence: Teaching, learning, relating. Sydney: University of New South Wales Press.

Birrell, C. (2007). Unpublished thesis. Meeting country: A deep engagement with place and Indigenous culture. Retrieved from http://arrow.uws.edu.au:8080/vital/access/ manager/Repository/uws:2519?query =birrell

Birrell, C., Gray, T., \& Preece, M. (2013). Ecopedagogies: Ways of connecting with the natural world through the Arts. Paper presented at the Linking Art and the Environment: EcoArts Australis Conference, 12-13 May 2013, Wollongong, NSW.

Brymer, E., Downey, G., \& Gray, T. (2009). Extreme sports as a precursor to environmental sustainability. Journal of Sport and Tourism, 14(2-3), 193-204.

Brymer, E., \& Gray, T. (2010). Developing an intimate relationship with nature through extreme sports participation. Leisure/Loisir, 34(4), 361-374.

Cameron, J. (2003). Decolonising nature: Strategies for conservation in a post-colonial era. In W. Adams and M. Mulligan (Eds.), Earthscan (pp. 172-196), London.

Cameron, J., \& San Roque, C. (2003). Coming into country: Catalysing a social ecology. Philosophy, Activism, Nature, 2, 76-88.

Carson, R. (1956). The sense of wonder. New York: Harper and Row.

Chawla, L. (2007). Childhood experiences associated with care for the natural world: $A$ theoretical framework for empirical results. Children, Youth and Environments, 17(4), 144170. Retrieved from http://www.colorado. edu/journals/cye.

Cheng,J.C.-H., \&Monroe, M.C. (2012). Connection to nature: Children's affective attitude toward nature. Environment and Behavior, 44, 31-49. doi:10.1177/0013916510385082
Cornell, J. (1998). Sharing nature with children: The classic parents' \& teachers' nature awareness guidebook (2nd ed., 20th anniversary ed.). Nevada City, CA: DAWN Publications.

Csikszentmihalyi, M. (1990), Flow: The psychology of optimal experience, New York: Harper and Row.

Dunlap, J., \& Kellert, S. (Eds.). (2012). Companions in wonder: Children and adults exploring nature together. Cambridge, MA: MIT Press.

Ellsworth, M. (2013). When logic isn't enough: Science + Arts $=$ Action. Keynote paper presented at the Linking Art and the Environment: EcoArts Australis Conference (pp. 14-15). 12-13 May, 2013, Wollongong, NSW, 13-15.

Fishbein, M., \& Ajzen, I. (1975). Belief, attitude, intention, and behavior: An introduction to theory and research. Reading, MA, Addison-Wesley.

Frauenfelder, G. (2011). Dramatic playfulness and the human spirit. In Wright, D., CamdenPratt, C. E., \& Hill, S. B. (Eds.). Social ecology: Applying ecological understandings to our lives and our planet (pp. 194-201). Stroud: Hawthorn.

Gray, T. (2012). Vitamin N: The missing ingredient in the 21st century curriculum. Retrieved from http://learning21c.wordpress.com/2012 /07/15/vitamin-n-the-missing-ingredient-inthe-21st-century-curriculum/

Gray, T. (2013). Overcoming ecophobia. Wildlife Australia, 42-44.

Gray, T., \& Birrell, C. (2013). Touched by the Earth: The impact of a multi-sensory immersion program on Year 7-8 students. Future faces: Outdoor education research innovations and visions. Paper presented at the Sixth International Outdoor Education Research Conference, Dunedin, New Zealand, 26-29 November.

Gray, T., \& Birrell, C. (2015). Touched by the Earth: A place-based outdoor learning programme incorporating the Arts. Journal of Adventure Education and Outdoor Learning, Retrieved from http://www.tandfonline.com/doi/abs/ 10.1080/14729679.2015.1035293 
Gray, T., \& Martin, P. (2012). The role and place of outdoor education in the Australian national curriculum. Australian Journal of Outdoor Education, 16(1), 39-50.

Green, M. (2012). Place, sustainability and literacy in environmental education: Frameworks for teaching and learning. Review of International Geographical Education Online, Volume 2, Number 3.

Gruenewald, D. (2003a). The best of both worlds: A critical pedagogy of place. Educational Researcher, 32(4), 3-12.

Gruenewald, D. (2003b). Foundations of place: A multidisciplinary framework for place-conscious education. American Educational Research Journal, 40(3), 619-654.

Herbert, T. (2008). Eco-intelligent education for a sustainable future life. In The contribution of early childhood education to a sustainable society (pp. 63-67). UNESCO.

Hinds, J., \& Sparks, P. (2008). Engaging with the natural environment: The role of affective connection and identity. Journal of Environmental Psychology, 28(2), 109-120.

Huxley, A. (1946). The perennial philosophy (1st edition). London: Harper and Brothers.

Jacobson, S., McDuff, M, \& Monroe, M. (2007). Promoting conservation through the arts: Outreach for hearts and minds. Conservation Biology, 21(1), 7-10.

Jones, J. (2013). Re-discovering the arts: The impact of engagement in a natural environment upon pre-service teacher perceptions of creativity. Thinking Skills and Creativity. Volume 8, 102-108.

Kahn, P., \& Kellert, S. (Eds.). (2002). Children and nature: Psychological, sociocultural, and evolutionary investigations. Cambridge, MA: MIT Press.

Kellert, S. (2002). Experiencing nature: Affective, cognitive, and evaluative development in children. In P. H. J. Kahn, \& S. R. Kellert (Eds.), Children and nature: Psychological, sociocultural, and evolutionary investigations (pp. 117-151). Cambridge, MA: MIT Press.
Kellert, S. (2012). Birthright: People and nature in the modern world. New Haven, CT: Yale Press. Retrieved from http://learning21c.wordpress .com/2013/04/08/children-nature-and-thefuture-of-our-species/

Kollmuss, A., \& Agyeman, J. (2002). Mind the gap: Why do people act environmentally and what are the barriers to pro-environmental behaviour? Environmental Education Research, 8(3), 239-260.

Kudryavtsev, A., Stedman, R. C., \& Krasny, M. E. (2011). Sense of place in environmental education. Environmental Education Research, 18(2), 229-250. doi:10.1080/13504622.2011. 609615

LeDoux, J. (1992). Emotion and the amygdala. In Agglington, A.P. (ed.), The amygdala: Neurobiological aspects of emotion, memory and emotional dysfunction. New York: Wiley-Liss.

LeDoux, J. (1997). The emotional brain: The mysterious underpinnings of emotional life. New York: Simon \& Schuster.

LeDoux, J. (2003). Synaptic self: How our brains become who we are. New York: Penguin Books.

Liefländer, A. K., Fröhlich, G., Bogner, F. X., \& Schultz, P. W. (2012). Promoting connectedness with nature through environmental education. Environmental Education Research, 19(3), 370-384. doi:10.1080/13504 622.2012.697545

Lloyd, A., \& Gray, T. (2014). Outdoor learning and the importance of environmental sustainability in Australian Primary Schools. Journal of Sustainability Education. Retrieved from http://www.jsedimensions.org/wordpress/ content/place-based-outdoor-learning -and-environmental-sustainability-with in-australian-primary-school_2014_10/

Louv, R. (2008). Last child in the woods: Saving our children from nature-deficit disorder. Chapel Hill, NC: Algonquin Press.

Martin, P. (2005). Human to nature relationships through outdoor education. In T.J. Dickson, T. Gray \& B. Hayllar (Eds.), Outdoor and experiential learning: Views from the top (pp. 28-52). Dunedin, New Zealand: Otago University Print. 
Milton, K. (2002). Loving nature: Towards an ecology of emotion. London: Routledge.

Mullins, P.M. (2011). A phenomenological approach to canoe tripping: Applicability of the dwelling perspective (Doctoral dissertation). Faculty of Physical Education and Recreation, University of Alberta, Edmonton.

Mullins, P.M. (2014). A socio-environmental case for skill in outdoor adventure. Journal of Experiential Education, 37(2), 129-143.

Nicholls, V., \& Gray, T. (2008a). Bush and adventure therapy: Letting nature in. Park Watch, March, No 232, 22-23.

Nicholls, V., \& Gray, T. (2008b). Sense and sensibility: Reality and romanticism in human/ nature relationships. In Mitten, D. \& Itin, C. M. (Eds.), Connecting with the essence of adventure therapy. Boulder, CO: Association for Experiential Education.

Nicholls, V., \& Gray, T. (2009). The role of stillness and quiet when developing human/nature relationships. Australian Journal of Outdoor Education, 11(1), 19-25.

Nicholls, V., Gray, T., \& Hoban, G. (2008). Busy doing nothing: Researching the phenomenon of quiet time in outdoor experiential learning. The identity of experience: Challenges for experiential learning. 11th International Conference on Experiential Learning (ICEL) UTS. Sydney, 8-12 December, 2008.

Nisbet E. K., Zelenski, J. M., \& Murphy, S. A. (2009). The nature relatedness scale: Linking individuals' connection with nature to environmental concern and behavior. Environment and Behaviour, 41(5), 715-740.

Norse, E. A. (1993). Global marine biological diversity: A strategy for building conservation into decision making. Washington, DC: Island Press.

Orr, D. W. (1993). Love it or lose it: The coming biophilia revolution. In Kellert, S. R. \& Wilson, E. O. (Eds.), The biophilia hypothesis (pp. 425440). Washington, DC: Shearwater Books/ Island Press.
Orr, D W. (2002). Political economy and the ecology of childhood. In P. H. Kahn \& S. R. Kellert (Eds.), Children and nature: Psychological, sociocultural, and evolutionary investigations (pp. 279-304). Cambridge, MA: Massachusetts Institute of Technology Press.

Orr, D.W. (2004). Earth in mind: On education, environment, and the human prospect. Washington, DC: Island Press.

Payne, P., \& Wattchow, B. (2008). Slow pedagogy and placing education in post-traditional outdoor education. Australian Journal of Outdoor Education, 12(1), 25-38

Perkins, H. E. (2010). Measuring love and care for nature. Journal of Environmental Psychology, 30(4), 455-463.

Plumwood, V. (2000). Belonging, naming and decolonization. Ecopolitics: Thought and Action. 1(1), 90-106.

Plumwood, V. (2003). Decolonising relationships with nature. In W. A. Adams \& M. Mulligan (Eds.), Decolonising nature: Strategies for conservation in a post-colonial era (pp. 51-78). London: Earthscan Publications, Ltd.

Pooley, J., \& O'Connor, M. (2000). Environmental education and attitudes: Emotions and beliefs are what is needed. Environment and Behavior, 32, 711-723 doi:10.1177/0013916500325007

Quay, J. (2015). Understanding life in school: From the academic classroom to outdoor education. Houndmills, Basingstoke, Hampshire: Palgrave Macmillan.

Sanger, M. (1997). Sense of place in education. The Journal of Environmental Education, 29(1), 4-8.

Selhub, E., \& Logan, A. (2012). Your brain on nature: The science of nature's influence on your health, happiness and vitality. Somerset: Wiley.

Sobel, D. (1996). Beyond ecophobia: Reclaiming the heart in nature education. Nature Literature Series Society, Great Barrington, MA: The Orion USA.

Sobel, D. (1999). Beyond ecophobia: Reclaiming the heart in nature education. Nature Study, $49,4-12$. 
Somerville, M., Davis, B., Power, K. Gannon, S., \& de Carteret, P. (2011). Place pedagogy change. Rotterdam: Sense.

Stern, D. (1985). The interpersonal world of the infant. New York: Basic Books.

Thoreau, H.D. (1858) The Henry David Thoreau Journals, Jan 25, 1858. Retrieved from http:// blogthoreau.blogspot.com.au/2014/01/ love-crust-of-earth-thoreaus-journal-25. html
Upitis, R. (2011). Arts education for the development of the whole child. Prepared for the Elementary Teachers' Federation of Ontario, Canada.

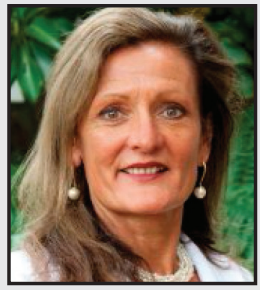

Tonia Gray's 30-year teaching career has been devoted to the benefits of outdoor learning for humanity. As a multi award-winning pedagogue, in 2014, she received a prestigious Office of Learning and Teaching (OLT) Australian Award for University Teaching for Excellence in outdoor experiential education. The nexus of Tonia's research and teaching explores human-nature relationships and their impact on well-being and personal development. She is a Senior Researcher in the Centre for Educational Research at Western Sydney University, and Tonia's research spans a wide cross-section of nature infused teaching and learning initiatives.

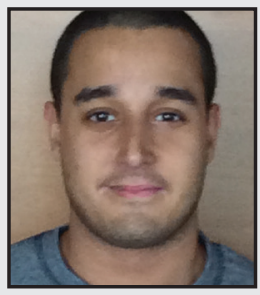

Cameron Thomson is a pre-service English educator who is interested in the impacts and benefits of nature-infused learning experiences for secondary learners. Cameron is interested in how outdoor stays can help produce innovative indoor pedagogies and is currently working in settings incorporating elements of Aboriginal and Torres Strait Islander 8-WAY learning methods in the outdoors to make cultural teaching and learning more transformative. 